\title{
Pre-Service Teacher Experiences of the 5E Instructional Model: A Systematic Review of Qualitative Studies
}

\author{
Serife Turan ${ }^{1 *}$ \\ ${ }^{1}$ Texas Tech University, Lubbock, TX, USA
}

Received 3 October 2020 - Accepted 6 May 2021

\begin{abstract}
This systematic review of qualitative studies was conducted to identify the factors that influence how pre-service science/math teachers implement the $5 \mathrm{E}$ instructional model and the challenges and barriers they face in doing so. Sixteen studies were identified in various electronic databases, and a meta-ethnography method was used to review the qualitative studies. The findings illustrate that the experiences of the pre-service teacher varied. Time, resources, method courses, training, field experience, beliefs, content knowledge, and classroom size were identified as influences on the practice of pre-service teachers. To sum up, this review provides a better understanding of pre-service teacher experiences in implementing the $5 \mathrm{E}$ instructional model.
\end{abstract}

Keywords: science/math, pre-service teacher, 5E instructional model, meta-ethnography, qualitative studies

\section{INTRODUCTION}

One factor that supports the teacher's outlining of a math and science lesson is the application of instructional models concerning the pattern of sequence of a daily lesson or unit plan (Bybee, 2014). A pattern of sequence can be a practical tool that the teacher uses to plan learning experiences tailored to daily lessons of any subject. Therefore, Bybee et al. (2006) suggested the 5E sequence (engagement, exploration, explanation, elaboration, and evaluation) as critical components of an effective lesson.

Effective instructional models should be based on learning theories; the $5 \mathrm{E}$ instructional model is based on the constructivist learning theory. Empirical studies suggest that the $5 \mathrm{E}$ instructional model is useful for teaching and learning (e.g., Toraman \& Demir, 2016; Walia, 2012) as it helps teachers develop practical student-centered (constructivist learning environment) lessons. The 5E instructional model serves as a flexible learning cycle that assists curriculum developers and classroom teachers in creating math/science lessons that incorporate constructivist, reform-based, teaching practices (Duran \& Duran, 2004). "Since the late 1980s, the $5 \mathrm{E}$ instructional model has been used extensively in the development of new curriculum materials and professional development experiences" (Bybee et al., 2006, p. 1).

Although the 5E instructional model was developed in 1980, the application of the learning cycle in classroom instruction remains a challenging task for teachers at all levels (e.g., Bybee et al., 2006; Yildiz \& Kocak Usluel, 2016). A number of factors have been identified to explain teachers' barriers to and challenges regarding the implementation of the $5 \mathrm{E}$ instructional model. These factors include: inadequate training to better understand how to create the math/science lesson (e.g., Biber et al., 2015), poor time management (Polgampala et al., 2016), working with colleagues who do not share similar inquiry-based views (e.g., Sickel \& Friedrichsen, 2015), lack of skills to transfer theory to the practice (e.g., Marshall \& Smart, 2013), classroom management problems encountered during implementation of the $5 \mathrm{E}$ instructional model (e.g., Polgampala et al., 2016), and so on. There is no argument that several of these factors time, training, and classroom management - are barriers to implementing the model in the lesson.

Having adequate resources, time, and training have been important in preparing teachers to competently integrate the 5E model into their classrooms successfully (Kirschner \& Selinger, 2003). A few studies have shown that in order to prepare pre-service teachers for effective

(c) 2021 by the authors; licensee Modestum. This article is an open access article distributed under the terms and conditions of the Creative Commons Attribution License (http://creativecommons.org/licenses/by/4.0/). 


\section{Contribution to the literature}

- This study identifies, compares, evaluates, and synthesizes qualitative studies' concerning the experiences.

- Pre-service math/science teachers have had with implementing the 5E instructional model.

- This study shows how pre-service teachers use the 5E instructional model in their lesson practices.

Table 1. Meta-Ethnography Steps

\begin{tabular}{|c|c|}
\hline Meta-ethnography Steps: & The researcher: \\
\hline 1. Getting started & selects the topic and area of interest \\
\hline 2. Deciding what is relevant to the initial interest & collects primary data and sets the inclusion criteria \\
\hline 3. Reading the studies & $\begin{array}{l}\text { extracts relevant information and begins analytical reading of the } \\
\text { primary data and concepts }\end{array}$ \\
\hline 4. Determining how the studies are related & identifies concepts related to the primary data \\
\hline 5. Translating studies into one another & develops shared conceptual categories \\
\hline 6. Synthesizing translations & constructs a line of argument \\
\hline 7. Expressing the synthesis & reports and discusses the findings \\
\hline
\end{tabular}

instructional model integration, teacher education programs need to help them build knowledge of sound pedagogical practices, skills, and content, as well as an understanding of how these concepts relate to one another (Atkins et al., 2008). On the other hand, to help in-service teachers, ongoing professional development that targets teachers' lack of skills can improve the quality of the lessons (Sickel \& Friedrichsen, 2015).

\section{THEORETICAL FRAMEWORK}

The principles of constructivism have been used to shape daily teaching practices in order to create more student-centered and effective learning environments. One of these practices based on constructivism is the $5 \mathrm{E}$ instructional model developed by Bybee (2006), the leading scientist in the Biological Sciences Curriculum Study (BSCS).

The $5 \mathrm{E}$ model is derived from the philosophical lineage of Johann Friedrich Herbart and John Dewey. The main idea behind constructivism is that individuals must be provided opportunities to construct their own knowledge and understanding (Herbart, 1901). Therefore, the learning environment needs to be designed as learner-centered, in which students are afforded opportunities to actively engage in the learning process (Dewey, 1971). In a learner-centered environment with the $5 \mathrm{E}$ instructional model, teacher and student roles are no longer traditional.

The purpose of this study is to provide a comprehensive review of the most useful suggestions for fidelity integration of the 5E instructional model in preservice teacher education programs and in-service professional learning experiences. More specifically, qualitative research studies were located, critically appraised, and findings synthesized to provide the evidence-based interventions necessary to prepare preservice teachers to integrate the model into their classroom practices and to help professional developers or teacher educators prepare practical professional experiences for the in-service teacher. Simply stated, this study investigated how math/science pre-service teachers use the 5E instructional model in their lesson practices. The research question that framed the metasynthesis of literature was: What were the experiences of math/science pre-service teachers after implementing the $5 \mathrm{E}$ instructional model?

\section{METHODOLOGY AND METHODS}

Qualitative studies in pre-service math/science teacher have focused on effective instructional model implementation as well as the pre-service teacher experiences with the 5E instructional model. However, there has been no systematic review of this body of research literature. This study reviewed and synthesized qualitative research studies in the field of math/science with a focus on factors that influenced pre-service science/math teachers' implementation of the $5 \mathrm{E}$ instructional model and also summarized their challenges and barriers.

The meta-ethnography model, which is the most commonly used method in most published metasynthesis studies (Barnett-Page \& Thomas, 2009), was adopted for the study and allowed for the synthesize of a wide variety of studies (Atkins et al., 2008; Campbell et al., 2003). The meta-ethnography approach adopted for this study was carried out in seven steps (Noblit \& Hare, 1988) as noted in Table 1. Each of these steps has been briefly described in detail in the following sections.

\section{Step 1: Getting Started}

The focus of this qualitative meta-synthesis was revised through reading the individual qualitative studies. The objective the study was to synthesize the qualitative research on pre-service math/science teachers' implementation of the 5E instructional model. 


\section{Step 2: Deciding What is Relevant to Initial Interest}

Both narrow and broad comprehensive search procedures were used to locate relevant studies.

\section{Selection terms}

The first selection of articles was generated by specifying the choice of keywords and databases for electronic search. This technique maximized the number of possibly relevant articles recovered and ensured the highest level of rigor (Shaw, Booth, \& Sutton, 2004). Keywords were chose based upon preliminary searches and in consulting with the second author. Three clusters of keywords were used:

- the target topic (e.g., 5E instructional model, 5E model, 5E learning cycle),

- the participants (e.g., pre-service teachers, math teachers, science teachers), and

- the qualitative research (e.g., qualitative research, interviews, focus groups, case study, mixed methods).

The search and retrieval process were further refined based on a number of parameters, including target topic, the sample, the methods, and the date of publication (Ludvigsen et al., 2016).

\section{Year of publication}

Only articles published in or after 1990 were selected. Although the 5E instructional model was developed in 1980 by Roger Bybee and colleagues, the model was relatively unknown until 1990.

\section{Meta-sources and databases}

Meta-sources (e.g., EBSCO and ERIC) and databases (e.g., Web of Knowledge, Academic Search Ultimate, JSTOR, MEDLINE Complete, PsycARTICLES, ScienceDirect, SCOPUS, SocINDEX with Full Text, Wiley and Blackwell Online Library) were systematically searched using the selection terms. Additionally, full texts were searched in Google Scholar and the ResearchGate platform. During the first search, 27 research studies were found (see Appendix A).

\section{Step 3: Selecting Studies}

After locating the possible appropriate studies, each needed to be evaluated to determine whether it should be included and further examined. This called for a deeper reading of each study. Studies in which teachers' perceptions and experiences of the $5 \mathrm{E}$ instructional model math/science classroom contexts were examined.

\section{Inclusion criteria}

Inclusion criteria consisted of qualitative or mixed methods studies, peer-reviewed studies, use of primary data, participants were pre-service science or math teachers, and published in or after 1990. After reading the title, abstract, study focus, research question(s), setting, and noting information about the participants of each study, there were 25 qualitative/mixed methods studies that focused on pre-service math/science teachers which met the inclusion criteria. Two other studies were not qualitative or mixed methods in nature (see Appendix A).

Appendix A presents whether the study involved math or science pre-service teachers, the study's method (i.e., qualitative, mixed methods, or quantitative), the study's context/setting (i.e., university methods course or professional development), and whether the studies were conducted in the United States or another country. The BSCS 5E instructional model has had a significant impact on the teaching and learning science not only the United States but also internationally (Bybee et al., 2006).

\section{Exclusion criteria}

Studies in which students' success was explored/examined after implementation of the model in a classroom setting were excluded. Studies were also excluded if the author(s) used close-ended survey questions to collect data, did not organize their qualitative data by theme, or presented findings that did not reflect teacher experiences. Of the initial 25 qualitative studies that had met the inclusion criteria, eight studies were excluded because the authors analyzed their qualitative data by calculating frequencies and/or did not conduct interviews (see Appendix B).

After reading the full text of all studies, 16 studies were carried forward for further quality assessment (see Table 2). After eliminating studies based on exclusion criteria, the details of the remaining studies-foci, settings, participants, methods, and findings-were recorded.

For those 16 studies, two studies were focused on only math pre-service teachers, 12 studies focused on only science pre-service teachers, two studies focused on both math/science pre-service teachers. The 16 studies included three mixed methods studies and 13 qualitative studies. Six of the studies were conducted in the United States, while the remaining 10 were international studies.

The researchers of those 16 studies each followed three specific steps in their research design. First, the delivery of the course focused on increasing the preservice teachers' awareness of the 5E instructional model and the development of the skills to implement it. Second, the researcher asked the pre-service teachers to create specific products (i.e., sample lesson, lesson plan). Third, the researchers conducted interviews to gather the reflections of the pre-service teachers, analyzed the products that were created (i.e., sample lesson, lesson plan), and interpreted the interviews (pre-service 
Table 2. Selected Studies

\begin{tabular}{|c|c|c|c|c|c|}
\hline Study & Participant & Design & Procedures & Data Analyse & Findings \\
\hline Althauser (2018) & 347 Math PST & $\begin{array}{l}\text { MMR, Qual Not } \\
\text { specify (Int, Obs) }\end{array}$ & $\begin{array}{l}3 \text { steps: Teach, } \\
\text { Apply, and Reflect }\end{array}$ & $\begin{array}{l}\text { Analytical } \\
\text { Coding }\end{array}$ & Organized themes \\
\hline $\begin{array}{l}\text { Bozdogan and } \\
\text { Altuncekic (2007) }\end{array}$ & 30 Science PST & $\begin{array}{l}\text { Descriptive Qual } \\
\text { Study (Int, Doc) }\end{array}$ & $\begin{array}{l}3 \text { steps: Teach, } \\
\text { Apply, and Reflect }\end{array}$ & Content analysis & $\begin{array}{l}\text { Calculated frequency } \\
\text { Organized themes }\end{array}$ \\
\hline $\begin{array}{l}\text { Celik, Pektas, and } \\
\text { Karamustafaoglu } \\
(2018)\end{array}$ & 40 Science PST & $\begin{array}{l}\text { Qual Research } \\
\text { (Int) }\end{array}$ & $\begin{array}{l}3 \text { steps: Teach, } \\
\text { Apply, and Reflect }\end{array}$ & Content analysis & Organized themes \\
\hline $\begin{array}{l}\text { Demirbas and } \\
\text { Pektas (2015) }\end{array}$ & 40 Science PST & $\begin{array}{l}\text { Case Study (Int, } \\
\text { Obs, Doc) }\end{array}$ & $\begin{array}{l}3 \text { steps: Teach, } \\
\text { Apply, and Reflect }\end{array}$ & Content analysis & $\begin{array}{l}\text { Calculated frequency } \\
\text { Organized themes }\end{array}$ \\
\hline $\begin{array}{l}\text { Duran, McArthur, } \\
\text { and Hook (2004) }\end{array}$ & 25 Science PST & Not specify (Int) & $\begin{array}{l}2 \text { Steps: Teach, } \\
\text { Reflect }\end{array}$ & Content analysis & Organized themes \\
\hline $\begin{array}{l}\text { Enugu and } \\
\text { Hokayem (2017) }\end{array}$ & 55 Science PST & $\begin{array}{l}\text { Case Study (Int, } \\
\text { Obs, Doc) }\end{array}$ & $\begin{array}{l}3 \text { steps: Teach, } \\
\text { Apply, and Reflect }\end{array}$ & Conten & $\begin{array}{l}\text { Calculated frequency } \\
\text { Organized themes }\end{array}$ \\
\hline $\begin{array}{l}\text { Fletcher and Luft } \\
\text { (2011) }\end{array}$ & 17 Science PST & $\begin{array}{l}\text { Case Study (Int, } \\
\text { Doc) }\end{array}$ & $\begin{array}{l}2 \text { Steps: Teach, } \\
\text { Reflect }\end{array}$ & Content & Organized themes \\
\hline $\begin{array}{l}\text { Iscan, Bayraktar, } \\
\text { and Gokce (2015) }\end{array}$ & $\begin{array}{l}15 \text { Math \& } \\
\text { Science PST }\end{array}$ & $\begin{array}{l}\text { Descriptive Qual } \\
\text { Study (Obs, Doc) }\end{array}$ & $\begin{array}{l}3 \text { steps: Teach, } \\
\text { Apply, and Reflect }\end{array}$ & Content & $\begin{array}{l}\text { Calculated frequency } \\
\text { Organized themes }\end{array}$ \\
\hline Metin et al. (2011) & 60 Science PST & Qual study (Int) & $\begin{array}{l}3 \text { steps: Teach, } \\
\text { Apply, Reflect }\end{array}$ & Content analysis & $\begin{array}{l}\text { Calculated frequency } \\
\text { Organized themes }\end{array}$ \\
\hline $\begin{array}{l}\text { Metin and Ozmen } \\
(2009)\end{array}$ & 25 Science PST & $\begin{array}{l}\text { Qualitative study } \\
\text { (Int, Obs) }\end{array}$ & $\begin{array}{l}3 \text { steps: Teach, } \\
\text { Apply, Reflect }\end{array}$ & Content analysis & $\begin{array}{l}\text { Calculated frequency } \\
\text { Organized themes }\end{array}$ \\
\hline $\begin{array}{l}\text { Smolleck and } \\
\text { Mongan (2011) }\end{array}$ & 38 Science PST & $\begin{array}{l}\text { MMR Qual Not } \\
\text { specify (Int) }\end{array}$ & $\begin{array}{l}3 \text { steps: Teach, } \\
\text { Apply, Reflect }\end{array}$ & Content analysis & $\begin{array}{l}\text { Calculated frequency } \\
\text { Organized themes }\end{array}$ \\
\hline $\begin{array}{l}\text { Namdar and Kucuk } \\
\text { (2018) }\end{array}$ & 51 Science PST & Case Study (Doc) & $\begin{array}{l}3 \text { steps: Teach, } \\
\text { Apply, Reflect }\end{array}$ & Content analysis & Organized themes \\
\hline $\begin{array}{l}\text { Polgampala, Shen, } \\
\text { and Huang (2016) }\end{array}$ & $\begin{array}{l}60 \text { Math \& } \\
\text { Science PST }\end{array}$ & $\begin{array}{l}\text { MMR, Qual Not } \\
\text { Specify (Int, Obs) }\end{array}$ & $\begin{array}{l}3 \text { steps: Teach, } \\
\text { Apply, and Reflect }\end{array}$ & Content & iized themes \\
\hline $\begin{array}{l}\text { Qablan and DeBaz } \\
\text { (2015) }\end{array}$ & 80 Science PST & $\begin{array}{l}\text { Qual Study (Int, } \\
\text { Doc) }\end{array}$ & $\begin{array}{l}3 \text { steps: Teach, } \\
\text { Apply, and Reflect }\end{array}$ & Content analysis & Organized themes \\
\hline $\begin{array}{l}\text { Varma, Wolkmann, } \\
\text { and Hanuscin (2009) }\end{array}$ & 40 Science PST & $\begin{array}{l}\text { Qual study (Int, } \\
\text { Doc) }\end{array}$ & $\begin{array}{l}2 \text { Steps: Teach, } \\
\text { Reflect }\end{array}$ & Content analysis & $\begin{array}{l}\text { Calculated frequency } \\
\text { Organized themes }\end{array}$ \\
\hline $\begin{array}{l}\text { Yildiz and Kocak- } \\
\text { Usluel (2016) }\end{array}$ & 47 Math PST & $\begin{array}{l}\text { Design-Based } \\
\text { Research (Int, } \\
\text { Obs, Doc) }\end{array}$ & $\begin{array}{l}3 \text { steps: Teach, } \\
\text { Apply, and Reflect }\end{array}$ & $\begin{array}{l}\text { Frequency and } \\
\text { content analysis }\end{array}$ & Organized themes \\
\hline
\end{tabular}

Note. Pre-Service Teacher (PST), In-Service Teacher (IST), Science (Sci), Mathematics (Math), Qualitative (Qual), Quantitative (Quan), Mixed Methods Research (MMR), Observation (Obs), Interview (Int), Document (Doc), Professional Development (PD), University Method Course (UMC).

teacher reflection). Findings in the studies were organized thematically or presented as a calculated frequency based on the researchers' evaluation or examination of the pre-service teachers' products (i.e., sample lesson, lesson plan) or interview.

\section{Step 4: Determining How the Studies are Related}

In Step 4, the studies were reread and concepts and themes were noted. The relationships between the frequent and recurring concepts arising from the papers were the focus. A summarization of the themes, categories, and codes has been provided (Table 3), along with supporting excerpts from the literature. Words and phrases have been bolded in Table 3 in order to make them stand out from the rest of the quote. As an organizational tool, the codes have been presented in the alphabetical order of the authors of the study. For example, in reading Althauser's (2018) study, the code "belief" emerged which also appeared in Fletcher and Luft's (2011) study. An excerpt from Fletcher and Luft's (2011) study "Teacher beliefs fluctuated depending upon the level of practical field experience of the teacher as well as the focus of instructor for the course" (p. 1143) was used for the example because this statement generated more than one code. 
Table 3. The Extracting Codes, Categories, and Themes from the Included Studies

\begin{tabular}{|c|c|c|}
\hline $\begin{array}{l}\text { Themes / } \\
\text { Concepts }\end{array}$ & Categories & Codes \\
\hline Barriers & $\begin{array}{l}\text { To } \\
\text { understanding } \\
\text { the } 5 \mathrm{E} \\
\text { instructional } \\
\text { model }\end{array}$ & $\begin{array}{l}\diamond \text { Belief (Althauser, 2018; Fletcher \& } \\
\text { Luft, 2011; Smolleck and Mongan } \\
\text { (2011) } \\
\diamond \text { Transition theory to practice (Duran } \\
\text { et al., 2004; Enugu \& Hokayem, } 2017 \\
\text { Fletcher \& Luft, 2011; Varma et al., } \\
\text { 2009) } \\
\diamond \text { Resistant (Duran et al., 2004) } \\
\diamond \text { Lecture (Duran et al., 2004) } \\
\diamond \text { More method course (Duran et al., } \\
\text { 2004; Enugu \& Hokayem, 2017) } \\
\diamond \text { Field experience (Fletcher \& Luft, } \\
\text { 2010; Smolleck \& Mongan, 2011) }\end{array}$ \\
\hline
\end{tabular}

Excerpts from studies (T: Teacher, A: Author)

A: Teacher beliefs fluctuated depending upon the level of practical field experience of the teacher as well as the focus of instructor for the course (Fletcher \& Luft, 2011, p. 1143).

; T: For me, growing up in a lecture-based, note-taking classroom, I wasn't used to it. The transition was frustrating (Duran et al., 2004, p. 162).

T: I think it (the 5E instructional model) is a good way to teach students, but I don't want to be taught that way (Duran et al., 2004, p. 162).

T: I really don't know how I am teaching biology because the class that I took was primarily lecture (Duran et al., 2004, p. 163).

T: I would say it's (method course) crucial. I would say it is very important and there should be more (Duran et al., 2004, p. 164).

$\mathrm{T}$ : We had a problem in dividing the lesson into the different 5Es (Enugu \& Hokayem, 2017, p. 190).

$\mathrm{T}$ : Like we had done some inquiry, but we didn't really know what it was called. And like we've heard the term thrown around before but never really applied it to teaching or how we could possibly teach that way (Varma et al., 2009, p. 9).

\begin{tabular}{|c|c|c|c|}
\hline Barriers & $\begin{array}{l}\text { To } \\
\text { implementing } \\
\text { the 5E } \\
\text { instructional } \\
\text { model }\end{array}$ & $\begin{array}{l}\diamond \text { Belief (Althauser, 2018; Fletcher \& } \\
\text { Luft, 2011; Smolleck and Mongan, } \\
\text { 2011) } \\
\nabla \text { Content (Bozdogan \& Altuncekic, } \\
\text { 2007; Celik et al., 2018; Demirbas \& } \\
\text { Pektas, 2015; Metin \& Ozmen, 2009) } \\
\nabla \text { Materials (Bozdogan \& Altuncekic, } \\
\text { 2007; Celik et al., 2018; Metin et al., } \\
\text { 2011; Metin \& Ozmen, 2009; Smolleck } \\
\text { \& Mongan 2011; Polgampala et al., } \\
\text { 2016) } \\
\nabla \text { Classroom Management (Bozdogan } \\
\text { \& Altuncekic, 2007; Celik et al., 2018; } \\
\text { Enugu \& Hokayem, 2017; Smolleck \& } \\
\text { Mongan 2011; Polgampala et al., } \\
\text { 2016) } \\
\text { Time (Bozdogan \& Altuncekic, 2007; } \\
\text { Celik et al., 2018; Demirbas \& Pektas, } \\
\text { 2015; Duran et al., 2004; Enugu \& } \\
\text { Hokayem, 2017; Fletcher \& Luft, } \\
\text { 2011; Metin et al., 2011; Metin \& } \\
\text { Ozmen, 2009; Smolleck \& Mongan } \\
\text { 2011; Polgampala et al., 2016) } \\
\diamond \text { Subject (Demirbas \& Pektas, 2015; } \\
\text { Metin et al., 2011 ; Polgampala et al., } \\
\text { 2016). } \\
\nabla \text { Colleagues (Enugu \& Hokayem, } \\
\text { 2017; Fletcher \& Luft, 2011 ; Smolleck } \\
\text { and Mongan, 2011) }\end{array}$ & $\begin{array}{l}\text { T: ...can be applied to science education but I think it } \\
\text { is very difficult to be applied to social studies } \\
\text { (Polgampala et al, 2016, p. 40). } \\
\text { T: I think the most important factor about not using } \\
\text { the 5E model for teacher is lack of learning material } \\
\text { (Metin et al., 2011, p. 417). } \\
\text { T: Probably the biggest issue with which I struggle as } \\
\text { a teacher is classroom management (Polgampala et } \\
\text { al., 2016, p. 41). } \\
\text { T: I will actively use the method in my classes if more } \\
\text { hours are allocated to science classes (Demirbas \& } \\
\text { Pektas, 2015, p. 60). } \\
\text { A: Cooperative teachers/field placement play an } \\
\text { important role in carving the PSTs' career of teaching } \\
\text { (Enugu \& Hokayem, 2017, p. 193). } \\
\text { T: Having a specific time for each 'E' is kind of hard } \\
\text { because it is based on individual lessons. Some } \\
\text { lessons might take less time, but some might go over } \\
\text { (Enugu \& Hokayem, 2017, p. 189). } \\
\text { T: ...I just don't know how schools give you the time } \\
\text { to think though. I like it all, but I am scared. I've } \\
\text { talked to a lot of student teachers and graduates who } \\
\text { say they don't use 5E or inquiry. They may write it } \\
\text { up, but it ends up being straight lecture ... (Fletcher } \\
\text { \& Luft, 2011, p. 1141). } \\
\text { A: Teachers' beliefs, which play an important role in } \\
\text { the early career development of a teacher (Fletcher \& } \\
\text { Luft, 2011, p. 1142). }\end{array}$ \\
\hline
\end{tabular}


Table 3 (continued). The Extracting Codes, Categories, and Themes from the Included Studies

\begin{tabular}{|c|c|c|c|}
\hline $\begin{array}{l}\text { Themes / } \\
\text { Concepts }\end{array}$ & Categories & Codes & Excerpts from studies (T: Teacher, A: Author) \\
\hline \multirow[t]{5}{*}{ Challenges } & $\begin{array}{l}\text { To } \\
\text { implementing } \\
\text { the engagement } \\
\text { step }\end{array}$ & $\begin{array}{l}\text { Finding Activity (Demirbas } \\
\text { \& Pektas, 2015; Iscan et al., } \\
\text { 2015; Metin \& Ozmen, 2009; } \\
\text { Namdar \& Kucuk, 2018; } \\
\text { Yildiz \& Kocak Usluel, 2016) }\end{array}$ & $\begin{array}{l}\text { T: We could not find an active engage activity while } \\
\text { doing our own plans (Yildiz \& Kocak Usluel, 2016, p. 24). }\end{array}$ \\
\hline & $\begin{array}{l}\text { To } \\
\text { implementing } \\
\text { the exploration } \\
\text { step }\end{array}$ & $\begin{array}{l}\text { Missing interaction and } \\
\text { discussion (Demirbas \& } \\
\text { Pektas, 2015; Iscan et al., } \\
\text { 2015) }\end{array}$ & $\begin{array}{l}\text { A: The pre-service teachers did not provide enough } \\
\text { opportunities for their students to make comparisons, } \\
\text { interact with others, discuss their ideas after conflicting } \\
\text { situations (Iscan et al., 2015, p. } 323 \text { ). }\end{array}$ \\
\hline & $\begin{array}{l}\text { To } \\
\text { implementing } \\
\text { the explanation } \\
\text { step }\end{array}$ & $\begin{array}{l}\diamond \text { Teacher-centered (Enugu \& } \\
\text { Hokayem, 2017; Namdar \& } \\
\text { Kucuk, 2018; Yildiz \& Kocak } \\
\text { Usluel, 2016) } \\
\diamond \text { Address misconception } \\
\text { (Iscan et al., 2015; Metin \& } \\
\text { Ozmen, 2009) }\end{array}$ & $\begin{array}{l}\text { A: Rather than discussing the results of the experiments as } \\
\text { mentioned in their lesson plan, they skipped the } \\
\text { discussion part and read out definitions directly from the } \\
\text { slides (Enugu \& Hokayem, 2017, p. 184). } \\
\text { A: PST missed removing misconceptions about the } \\
\text { subject material in order to enable students to more } \\
\text { readily learn new concepts (Iscan et al., 2015, p. 324). }\end{array}$ \\
\hline & $\begin{array}{l}\text { To } \\
\text { implementing } \\
\text { the elaboration } \\
\text { step }\end{array}$ & $\begin{array}{l}\diamond \text { Activity (Enugu \& Hokayem, } \\
\text { 2017; Iscan et al., 2015; Metin } \\
\text { \& Ozmen, 2009; Namdar \& } \\
\text { Kucuk, 2018) }\end{array}$ & $\begin{array}{l}\text { T: The elaborate part for me was always a little bit more } \\
\text { vague or harder to do (Enugu \& Hokayem, 2017, p. 188). }\end{array}$ \\
\hline & $\begin{array}{l}\text { To } \\
\text { implementing } \\
\text { the evaluation } \\
\text { step }\end{array}$ & $\begin{array}{l}\checkmark \text { Lack of assessment (Enugu \& } \\
\text { Hokayem, 2017; Iscan et al., } \\
\text { 2015; Metin \& Ozmen, 2009; } \\
\text { Namdar \& Kucuk, 2018; } \\
\text { Yildiz \& Kocak Usluel, 2016) }\end{array}$ & $\begin{array}{l}\text { A: Pre-service teachers rarely assessed learners' } \\
\text { knowledge and skills (5 times). (Iscan et al., 2015, p. 325). } \\
\text { T: Evaluating students understanding at the end of the } \\
\text { lesson was challenging (Enugu \& Hokayem, 2017, p. 186). }\end{array}$ \\
\hline \multirow[t]{2}{*}{ Requirement } & $\begin{array}{l}\text { Associated with } \\
\text { teacher }\end{array}$ & $\begin{array}{l}\Delta \text { Knowledge (Bozdogan \& } \\
\text { Altuncekic, 2007; Celik et al., } \\
\text { 2018) } \\
\diamond \text { Time (Duran et al., 2004; } \\
\text { Enugu \& Hokayem, 2017; } \\
\text { Metin et al., 2011; Smolleck } \\
\text { and Mongan, 2011) } \\
\diamond \text { Content knowledge (Enugu } \\
\text { \& Hokayem, 2017; Celik et } \\
\text { al., 2018; Metin et al., 2011; } \\
\text { Smolleck \& Mongan, 2011) }\end{array}$ & $\begin{array}{l}\text { T: First we need to know the topic well. Therefore, long } \\
\text { time research is required...Separated activity need to be } \\
\text { comprehensible. This takes a long time and wearies the } \\
\text { brain (Metin et al., 2011, p. 418). } \\
\text { T: 5E model is the forefront of concept teaching as it is } \\
\text { aimed to learn and comprehend information directly. } \\
\text { Therefore, teacher knowledge is important (Celik et al., } \\
\text { 2018, p. 18). } \\
\text { A: Strong science content knowledge helps PSTs design } \\
\text { good science lessons and provide complete scientific } \\
\text { explanation (Enugu \& Hokayem, 2017, p.192). }\end{array}$ \\
\hline & $\begin{array}{l}\text { Associated with } \\
\text { school }\end{array}$ & $\begin{array}{l}\Delta \text { Environment (Metin et al., } \\
\text { 2011) } \\
\Delta \text { Classroom size (Metin et al., } \\
\text { 2011) } \\
\diamond \text { Training (Metin et al., 2011) }\end{array}$ & $\begin{array}{l}\text { T: If we assume that we practiced it to the classroom with } \\
50-60 \text { students, it was not possible to teach productively. } \\
\text { Therefore condition, the equipment of school and the case } \\
\text { of classroom and the environment are important for the } \\
5 \mathrm{E} \text { model's practicability (Metin et al., 2011, p. 416). }\end{array}$ \\
\hline
\end{tabular}

Four thematic clusters emerged during the analyses: Barriers, Challenges, Requirements, and Benefits. Each thematic cluster contains specific descriptors, which are categories. Similar to the theme, the meaning of each category was derived from specific excerpts and related to a particular code. For example, Barriers consisted of two categories. The category of understanding the $5 \mathrm{E}$ instructional model was further divided into six codes: belief, translating theory to practice, resistant, lecture, more method courses, and field experience, which affected a pre-service teacher in acquiring the skills need for implementing the $5 \mathrm{E}$ instructional model. The category of implementing the $5 \mathrm{E}$ instructional model consisted of the six codes: belief, content, materials, classroom management, time, subject, and colleagues, which affected the pre-service teachers' implementation of the $5 \mathrm{E}$ instructional model. In other words, the preservice teachers had difficulty not only during implementation but also in understanding the $5 \mathrm{E}$ instructional model.

The theme of Challenges arose during the pre-service teachers' field experiences. Challenges had five categories, each related to one of the 5Es. During the engagement phase, pre-service teachers were challenged to find activities to engage students. During the exploration phase, the pre-service teachers missed the opportunity to discuss and interact after the exploration 
phase; instead of encouraging students to discuss the concept, the teachers explained the concept. The elaboration phase was omitted by the pre-service teachers, as they did not plan an activity for this phase. The final phase, evaluation, should take place throughout the instruction; however, the pre-service teachers left evaluation to the end of the classroom.

The theme of Requirement consisted of two categories, which were associated with the teacher and associated with the school. Most of the studies recommended that the pre-service teachers need to be effective in using the $5 \mathrm{E}$ instructional model in the classroom. For example, knowledge, time, and content knowledge are requirements associated with the teacher. On the other hand, environment, classroom size, and training were associated with the school. The last theme of Benefit was related to teaching with the $5 \mathrm{E}$ instructional model and consisted of the seven codes of deeper understanding, fun, creative thinking, knowledge permanent, studentcentred, critical thinking, and phasing the lesson.

\section{Step 5: Translating Studies Into One Another}

In this step, relationships among the included studies were determined. The included studies were scanned across and reread to attain familiarity with the whole context of each study. The first-order construct (view of the teacher) was noted and linked to the second-order construct (interpretations of the author). These constructs and examples are also presented in Table 3. For example, Enugu and Hokayem (2017) concluded, "Strong science content knowledge helps pre-service teachers design good science lessons and provide complete scientific explanation" (p. 192). Upon reading this study, science content knowledge was noted as one requirement to implementing the $5 \mathrm{E}$ instructional model with fidelity.

\section{Step 6: Synthesizing the Translations}

In the sixth step, each part of the data (whole manuscripts) was coded and then grouped. In this step, each included study was again addressed in alphabetic order. I identified specific constructs (first order) within teachers' excerpts and within the interpretation (second order) of the author(s) the first and second studies had in common. I repeated the process with the first and second order constructs of the third and fourth studies until the entire list of studies was analyzed.

This step was very useful for developing third-order interpretations, which are based on both first- and second-order constructs (Atkins et al., 2008). Key and crucial themes found were consolidated into a line of argument (third-order interpretation). Developing a line of argument (Noblit \& Hare, 1988) involves comparing themes across studies, matching themes from one study with those from another while ensuring that each key theme captures similar themes from different studies.

\section{Step 7: Expressing the Synthesis}

In the final step, the most subjective step of the analyses, analytical themes were generated. These themes are presented in the findings section. The themes were organized into categories, which are interpretations of the themes and can be considered third-order interpretations.

For example, the theme of Requirement describes the pre-service teachers' needs for implementing the 5E instructional model. One of the pre-service teachers stated, "I need time to create lesson plan and sources to set up activity" (Bozdogan \& Altuncekic, 2007, p. 588). Bozdogan and Altuncekic (2007) interpreted this as a disadvantage; however, this statement was interpreted as a requirement in this study. The disadvantages of the $5 \mathrm{E}$ instructional model was not addressed because this theme would overlap with the requirement/barriers theme. The review of the literature indicated there were not disadvantages of the $5 \mathrm{E}$ instructional model; however, there are barriers to implementing the model.

\section{Final Step: Overstep From Step 2 to Step 7}

An update literature search was performed after writing the synthesis during which databases were again searched to locate any newly published studies. No additional studies resulted from the review of the databases.

\section{Trustworthiness}

The trustworthiness of the study was established by following the four criteria identified by Lincoln and Guba (1985): credibility, transferability, confirmability, and dependability.

Credibility for this study was met by examining a large number of studies. All of the studies were strategically scanned to select relevant studies based on inclusion and exclusion criteria. Additionally, the studies that met the inclusion criteria were carefully read and recorded. Details of the studies, such as foci, settings, participants, methods, and findings, were recorded. To ensure the credibility of the findings, an external auditor examined three studies from the research. The external auditor was a graduate student who had experience with the qualitative research methodology and was majoring in math education. Independently, the external auditor and first author examined the details of the studies' findings, themes, and excerpts. There was $85 \%$ agreement with the external auditor on the information recorded from the research studies into the tables. In addition, the findings were repeatedly checked by the second author.

Confirmability was promoted through the use of an "audit trail," which involved the disclosure of the 7-step research process and the data analysis. The audit trail for all data described in detail the methods of data 
collection, analyses, and interpretation. In addition, examples of the analyses and interpretations are provided.

To establish transferability of the findings, thick descriptions of processes are provided so the reader can determine to what extent the findings might transfer to another context (Lincoln \& Guba, 1985; Merriam, 1998). The procedures and how the analyses were conducted were explained, and an adequate description of the data is provided in the study for critical review of the findings by other researchers. Also, purposive research sampling ensured the transferability of the findings of the study to other contexts.

Lastly, dependability was established with the audit trail. The dependability audit can be created at the same time as the confirmability audit (Mertens, 1998). The entire process for each stage of inquiry, including the methodology of the study, was reviewed by the second author.

\section{RESULTS}

In this section, the research question "What were the experiences of math/science pre-service teachers after implementing the 5E instructional model?" is answered. Through following the seven steps, themes were extracted from the findings that pertained to pre-service science/math teachers' experiences.

\section{Barriers}

The main theme of the findings, Barriers, describe what prevented the pre-service teachers from implementing the 5E instructional model. Something to keep implementing the 5E instructional model. This theme was comprised of two categories: barriers to knowing the 5E instructional model and barriers to practicing the 5E instructional model.

There were four studies that reported the pre-service teachers had a hard time applying theory to practice (Duran et al., 2004; Enugu \& Hokayem, 2017; Fletcher \& Luft, 2011; Varma et al., 2009). While some pre-service teachers found this new way of teaching difficult, other pre-service teachers were willing to learn the $5 \mathrm{E}$ instructional model through the lecturing-teaching method (Duran et al., 2004). The pre-service science teachers claimed they needed more than just one methods course to learn how to implement the model in lesson practice (Duran et al., 2004; Enugu \& Hokayem, 2017). Fletcher and Luft (2011) also reported that preservice teachers needed more field experience in which to practice the model.

Knowing how to transfer theory (constructivism) to practice (5E instructional model) is paramount for students' learning, as stated by pre-service teachers (Bozdogan \& Altuncekic, 2007; Celik et al., 2018; Duran et al., 2004; Metin et al., 2011; Polgampala et al., 2016).
Nevertheless, there are factors that affect a teacher's ability to link practice to theory, such as (a) experiencing methods course activities that emphasize and practice constructivist learning theory, and (b) engaging in field experiences in which to practice the $5 \mathrm{E}$ instructional model.

Another category of barriers the implementation of the $5 \mathrm{E}$ instructional model was identified and was related to the varied experiences of the pre-service teachers. Five studies noted that the pre-service teachers encountered classroom management issues after the implementation of the model, such as time constraints and group work difficulty (Bozdogan \& Altuncekic, 2007; Celik et al., 2018; Enugu \& Hokayem, 2017; Polgampala et al., 2016; Smolleck \& Mongan 2011).

Several studies indicated that the 5E instructional model may not be appropriate for some science topics (Demirbas \& Pektas, 2015; Metin et al., 2011; Polgampala et al., 2016).

The barriers mentioned most frequently were that of limited time (Bozdogan \& Altuncekic, 2007; Celik et al., 2018; Demirbas \& Pektas, 2015; Duran et al., 2004; Enugu \& Hokayem, 2017; Fletcher \& Luft, 2011; Metin et al., 2011; Metin \& Ozmen, 2009; Smolleck \& Mongan 2011; Polgampala et al., 2016) and lack of materials (Bozdogan \& Altuncekic, 2007; Celik et al., 2018; Metin et al., 2011; Metin \& Ozmen, 2009; Smolleck \& Mongan 2011; Polgampala et al., 2016). Managing the time to use the 5E model in teaching and mapping the different lesson sequence of the $5 \mathrm{E}$ instructional model became barriers for some pre-service teachers (Duran et al., 2004; Enugu \& Hokayem, 2017) who were just learning these skills. The researchers noted having more time to practice and plan the $5 \mathrm{E}$ lesson plan as possible solutions.

The pre-service teachers' own teaching and learning beliefs were other barriers to be considered when seeking change in their instructional practices. Three studies (Althauser, 2018; Fletcher \& Luft, 2011; Smolleck \& Mongan, 2011) reported that teachers' beliefs about science/math, teaching science/math, and learning science/math directly influenced their classroom decisions and actions associated with teaching science/math. Supporting the pre-service teachers in shaping their views of teaching and learning will affect their beliefs and will ultimately change their practice.

The only barriers noted for 10 international studies were the subject being taught (language or social science), materials being used, and classroom management issues. Only one factor, "pre-service teacher beliefs," can be changed by the individual teacher, whereas time, lack of materials, class size, and support from other teachers are beyond the pre-service teachers' control. Hence, there is a need for educators and policymakers to address the various factors that influence a pre-service teacher's successful implementation of the 5E model. 
Another important point is that the pre-service teachers reconstructed their prior knowledge about the $5 \mathrm{E}$ instructional model during the methods course and further developed this knowledge by way of practice. Thirteen of the 16 studies examined for the metasynthesis followed three steps (Teach, Apply, and Reflect). In several studies the pre-service teachers' ideas about constructivist teaching were changed through these experiences (Althauser, 2018; Fletcher \& Luft, 2011; Smolleck \& Mongan, 2011).

\section{Challenges}

The theme of Challenges confirmed that the 5E instructional model was not only unfamiliar and difficult to implement for the pre-service teachers, but also implementing required effort and time. The challenges faced by the pre-service teachers in implementing the $5 \mathrm{E}$ instructional model are specifically applicable to each phase of the $5 \mathrm{E}$ model.

During the engagement phase of the $5 \mathrm{E}$ instructional model, pre-service teachers were challenged to find appropriate activities that would determine what students know or think about the topic (Demirbas \& Pektas, 2015; Iscan et al., 2015; Metin \& Ozmen, 2009; Namdar \& Kucuk, 2018; Yildiz \& Kocak Usluel, 2016).

During the exploration/explanation phase, preservice teachers found it challenging to shift instruction to a more learner-centered instructional model. Although the pre-service teachers planned a $5 \mathrm{E}$ instruction model, their classroom practice was not student-centered (Enugu \& Hokayem, 2017; Namdar \& Kucuk, 2018; Yildiz \& Kocak Usluel, 2016). In addition, pre-service teachers are likely to not address students' misconceptions during this phase (Iscan et al., 2015).

During the elaboration phase, pre-service teachers struggled to find appropriate activities for this phase of the 5E instructional model (Enugu \& Hokayem, 2017; Iscan et al., 2015; Metin \& Ozmen, 2009; Namdar \& Kucuk, 2018; Yildiz \& Kocak Usluel, 2016).

Pre-service teachers also struggled with evaluating students' understanding of the concepts (Enugu \& Hokayem, 2017; Iscan et al., 2015; Namdar \& Kucuk, 2018; Yildiz \& Kocak Usluel, 2016). Some of the preservice teachers did not have an assessment question that was tailored specifically to the content they taught (Enugu \& Hokayem, 2017); some of the questions were not clear to the students (Enugu \& Hokayem, 2017). The pre-service teachers often ran out of time during the evaluation phase, which led to asking students to finish their assessment at home (Iscan et al., 2015; Namdar \& Kucuk, 2018).

\section{Requirements for Planning and Implementing the 5E Model}

Seven requirements necessary to planning and implementing the 5E instructional model emerged from the synthesis of the studies. Those seven requirements comprise the two categories of "associated teacher" and "associated school." The planning and implementing of the $5 \mathrm{E}$ instructional model are a comprehensive undertaking that requires teacher effort and a supportive school environment, administration, and colleagues. Coordination and effective communication across administration and colleagues are especially necessary for the pre-service teacher to develop and enact the $5 \mathrm{E}$ instructional model and, thus, positively affect instruction (Sickel \& Friedrichsen, 2015)

Once the pre-service teachers are introduced to the $5 \mathrm{E}$ instructional model, they need time to plan and implement it (Duran et al., 2004; Enugu \& Hokayem, 2017; Metin et al., 2011). Many of the pre-service teachers were not able to estimate a realistic time period for implementing the 5E instructional model. Furthermore, there needs to be intentionality in allocating time for each of the 5E instructional phases (Duran et al., 2004).

Some researchers posited that, despite taking the science/math content knowledge courses which were necessary for implementing/teaching their lessons, the pre-service teachers still lacked the necessary content knowledge (Enugu \& Hokayem, 2017). Knowing how the $5 \mathrm{E}$ instructional model is to be implemented is a critical requirement (Bozdogan \& Altuncekic, 2007; Celik et al., 2018; Metin et al., 2011).

The requirements of time, content knowledge, and knowledge of the implementation of the 5E instructional model were associated with the teacher. However, other requirements were associated with the school. Some of the school requirements influenced how pre-service teachers' implemented of the 5E instructional model such as having the necessary resources. The resource requirement refers to the lack of equipment or materials (e.g., laboratory equipment) and supplementary materials (e.g., online access) that affect the implementation of the model (Demirbas \& Pektas, 2015; Metin et al., 2011). The absence of resources needed for inquiry lessons may cause pre-service teachers to be reluctant to implement the model. Other school related requirements included the physical learning environment, the large classroom size, and available training (Demirbas \& Pektas, 2015; Metin et al., 2011). The absence of any of these conditions affected preservice teachers' implementation of the model. Almost all of the requirement codes (i.e., environment, classroom size, training) were linked to international studies (Bozdogan \& Altuncekic, 2007; Celik et al., 2018; Demirbas \& Pektas, 2015; Duran et al., 2004; Metin et al., 2011; Polgampala et al., 2016).

The list of the requirements (e.g., knowledge, time, classroom environment) that emerged from metasynthesis appear to overlap with the barriers to implementing the $5 \mathrm{E}$ instructional model. If these 
requirements are not provided, they become barriers in implementing the $5 \mathrm{E}$ instructional model with fidelity.

\section{Benefits}

The theme of benefits refers to the advantages of implementing the 5E instructional model. The preservice teachers found that the $5 \mathrm{E}$ instructional model differed from the traditional model with the $5 \mathrm{E}$ instructional model characterized as being more student-centered (Bozdogan \& Altunçekiç, 2007; Celik et al., 2018; Metin et al., 2011), creating deeper understanding (Althauser, 2018), and improving students creative thinking and critical thinking (Bozdogan \& Altunçekiç, 2007; Celik et al., 2018; Polgampala et al., 2016; Qablan \& DeBaz, 2015).

During practicum experiences pre-service teachers and the students found the 5E instructional model to be a fun way to teach and learn. According to Althauser (2018), the 5E instructional model made math fun. Students were also more likely to retain knowledge gained from a fun environment (Bozdogan \& Altunçekiç, 2007; Celik et al., 2018; Duran et al., 2004; Metin et al., 2011; Polgampala et al., 2016).

The benefits of the $5 \mathrm{E}$ instructional model were emphasized only in international studies. The international researchers asked frequently about the benefits of the $5 \mathrm{E}$ instructional model during their interviews. Unfortunately, the pre-service teachers had a very limited and narrow perception of those benefits (Bozdogan \& Altunçekiç, 2007; Celik et al., 2018; Duran et al., 2004; Metin et al., 2011; Polgampala et al., 2016). The 5E instructional model was originally developed in the United States and then adapted by international researchers who emphasized the benefits of the $5 \mathrm{E}$ instructional model. U.S. teacher educators need to more strongly convey to pre-service teachers that incorporating the 5E instructional model into their lesson design helps students build a stronger foundation of knowledge through active, creative participation. As examples of support for using the $5 \mathrm{E}$ instructional model as an instructional strategy, Connecticut, Maryland, and Texas Education Agencies have strongly recommend the application of the 5E instructional model (Bybee et al., 2006).

\section{DISCUSSION}

The purpose of this qualitative meta-synthesis was to identify, compare, evaluate, and synthesize qualitative studies' concerning the experiences pre-service math/science teachers have had with implementing the $5 \mathrm{E}$ instructional model. This value of this study to the educational community is that the analysis and synthesis the 16 qualitative studies focused on the pre-service teachers classroom practices in regard to implementing the $5 \mathrm{E}$ instructional model.
By following a structured analysis approach (Noblit \& Hare, 1988), four themes emerged from the metasynthesis that were related to teacher experiences with implementing the 5E instructional model: Barriers, Challenges, Requirements, and Benefits. The analysis of the 16 studies has presented a general perception of preservice teachers' experiences and problems. These perceptions have been highlighted through excerpts from the original studies.

Qualitative research methods are increasingly used in education and some topics can be synthetized to reveal pattern and common threads (e.g., Atkins et al. 2008; Savenye \& Robinson, 2005). The 16 studies in this meta-synthesis show the pre-service teachers' experiences with implementing the $5 \mathrm{E}$ instructional model and also provide an insight about the complexities and nuances significant for understanding factors that influences teacher experiences.

Second, although the individual qualitative studies examined in this meta-synthesis did not involve a large number of participants, the aggregated set of studies involved over 400 pre-service teachers who attempted to implement the 5E instructional model. These 16 studies provide teacher educators with specific experiences of pre-service teachers. The discussion section was based on the prevalence of qualitative evidence presented in Table 3 and the Findings section.

Almost all the studies in this meta-synthesis highlighted some barriers or something that limited the pre-service teachers from implementing the $5 \mathrm{E}$ instructional model. However, the researchers could not control what influenced the pre-service teachers in implementing the $5 \mathrm{E}$ instructional model, such as their belief towards the 5E instructional model, the time needed to prepare and implement the model, the amount of encouraging support received by others in implementing the model, their personal knowledge of the content area being taught, the opportunities for field experiences and practice using the 5E model, the amount of teacher training and practice of the model, and the availability of resources. These factors are impossible to ignore because they have a great effect on the implementation of the model (Althauser, 2018; Fletcher \& Luft, 2011). Colleagues were influential supports when implementing the $5 \mathrm{E}$ instructional model, as interactions with these colleagues impacted teaching practice (Enugu \& Hokayem, 2017; Fletcher \& Luft, 2011).

The meta-synthesis uncovered various challenges when the teacher had a limited understanding of the $5 \mathrm{E}$ instructional model, and these varied for each of the phases. Pre-service teachers sometimes had difficulty finding activities related to the phases of engagement and elaboration. During the explanation phase, the preservice teachers used a more teacher-centered approach. 
The pre-service teachers also did not use time effectively when evaluating students.

The meta-synthesis revealed that a number of preservice teachers were unsure about the requirements and roles they would take in implementing 5E instructional model. When pre-service teachers identify and adopt the thinking behind the 5E instructional model, they are able to transform their practice, instead of simply using the sequence of the $5 \mathrm{E}$ instructional model while maintaining their traditional practice (Spillane \& Zeuli, 1999).

The findings that emerged from the meta-synthesis concerning the barriers and challenges uncovered that most of the studies emphasized requirements for planning and implementing the 5E instructional model, such as the physical learning environment, the large classroom, training, content knowledge, and the knowledge of the 5E instructional model. The findings also highlighted that there was a critical need for preservice teachers to experience methods courses that prepared them with deep content knowledge as well as how to easily find resources. According to Turan and Matteson (2020) during university method courses, teachers have engaged in constructivist environments, but they do not adopt the 5E instructional model. Perhaps this is because they have not been enough practice in how to use it. This study identified specific challenges of using the 5E instructional model. Connecting this model is an essential step in supporting preservice teachers to facilitate effective studentcentered classrooms and provide in-service teachers targeted professional development to improve their lessons' quality. If teachers recognize and adopt the thinking behind the 5E instructional model, they will transform their practice.

In analyzing the 16 studies, the advantages realized by the pre-service teacher after the implementation of the $5 \mathrm{E}$ instructional model were coded under the theme of benefits. Although the pre-service teachers encountered some barriers and challenges in the implementation of the 5E instructional model, they saw that students benefitted from the model due to the lessons being more fun and that students were motivated to engage in the learning events, developed a deeper understanding of the material, and used creative and critical thinking skills. The pre-service teachers stated that the 5E instructional model was studentcentered, led students to demonstrate permanent knowledge, and assisted in sequencing the lesson.

The teacher educators in the studies examined in this meta-synthesis were integrating the 5E instructional model into a university pre-service teacher education program. This led the teacher educators to collect data on the implementation of the 5E instructional model with pre-service teachers in order to investigate how the $5 \mathrm{E}$ instructional model and related learning experiences facilitated the pre-service teachers understanding, knowledge, skills. The researchers for three of the studies in the meta-synthesis only taught the $5 \mathrm{E}$ instructional model and asked the pre-service teachers for their opinions on the model. The other 13 studies followed three steps: Teach, Apply, and Reflect. The researchers argued that the $5 \mathrm{E}$ instructional model could be used across disciples (e.g., science, math), with students from primary school to college, and taught to in-service or pre-service teachers through professional development opportunities or a university methods course.

Bybee et al. (2006) stated that the 5E model had been used for science and mathematics content, with supporting evidence to suggest that this model could be used effectively in any subject area. When the model was implemented in one lesson, the pre-service teachers complained about the time spent in addressing all of the cycle (Duran et al., 2004; Enugu \& Hokayem, 2017). The meta-synthesis of the studies also noted the code of "time" was listed as a theme in the areas of barriers, challenges, and requirements. However, Bybee (2014) stated that the 5E instructional model was best used for a unit of 2 or 3 weeks in length, during which each phase is one or more distinct lessons.

The meta-synthesis found that pre-service teachers benefit from experiences with teaching and learning with the 5E instructional model in their methods courses, during their field experiences, and even their first year of teaching experiences (Sickel \& Friedrichsen, 2015). However, there was a suggestion that teacher educators support the pre-service teachers' transition into student teaching and beyond (Sickel \& Friedrichsen, 2015).

All of the factors identified through the metasynthesis have implications for both pre-service teacher training and in-service teacher professional development. Furthermore, for reform to become widespread and sustained the barriers and challenges that have been reported in the selected studies need to be considered. Educational reform does not become widespread and sustained until after sufficient time has elapsed. One initial step would be to determine how the divide between theory and practice could be bridged when pre-service teachers are provided opportunities to apply theory to practice and derive theory from practice (Enugu \& Hokayem, 2017).

\section{LIMITATION}

One limitation of this study is the low number of applicable studies that were examined for the metasynthesis. Additional studies would have provided a broader picture of pre-service teachers' experiences in implementing the 5E instructional model in science and mathematics classrooms. Several studies were missing interview or observation report details. Additionally, 
details of the original study design may have been affected by journal page limits. Limitations of this metasynthesize also include the exclusion of several types of study designs, including action research studies, research reports, unpublished work, and research studies still in progress.

\section{FUTURE RESEARCH}

The results of this study provide many paths of research on the $5 \mathrm{E}$ instructional model to pursue in the future. Among the questions to investigate are: Why do teachers of different subjects have different experiences with implementing the 5E instructional model? Another area for research lies in the congruence between preservice teachers' belief to teach with the $5 \mathrm{E}$ instructional model and pre-service teachers' field experiences to implement the model in their practice. A third area to explore would be the different experiences of science and language arts teachers in their perceptions of the $5 \mathrm{E}$ instructional model. Additionally, researchers might want to investigate the long-term changes, if any, in the pre-service teachers' use of the $5 \mathrm{E}$ instructional model as they progress to student teaching and then become actual practicing teachers.

\section{RECOMMENDATION}

The positive impact of the $5 \mathrm{E}$ instructional model has varied (e.g., Bybee et al., 2006; Toraman \& Demir, 2016; Walia, 2012). The 5E instructional model appears to be most successful when the teacher applies the model with fidelity (e.g., Walia, 2012). Pre-service teachers who have had adequate learning experiences in inquiry instruction have been shown to apply the $5 \mathrm{E}$ instructional model of instruction (Sickel \& Friedrichsen, 2015).

There were several additional benefits of the $5 \mathrm{E}$ instructional model that emerged during the metasynthesis. For example, the 5E instructional model promoted deeper understanding of content, helped learning to be fun, pushed students to engage in creative thinking and critical thinking, helped knowledge to become more permanent, was student-centered, and helped in sequencing the lesson phases.

The following recommendations are based on the findings of this meta-synthesis.

- Researchers must investigate how to better prepare pre-service teachers as they transition from the university to their own classrooms and what helps them to hold onto sound instructional practices in the face of difficulties of time and environment.

- Improvements are needed in university methods courses in teaching pre-service teachers to implement the 5E instructional model with fidelity. Additional quantitative and qualitative studies should be conducted with teachers of different subjects in U.S. and international settings to explore and examine the factors that affect preservice teachers' understandings about and practice with the $5 \mathrm{E}$ instructional model.

- There is a need to streamline the process of planning and implementing a student-centered learning lesson using the 5E instructional model. Teacher educators need to utilize the 5E instructional model template as a common tool to mediate the pre-service teacher's learning and application, as it adds the student-centered lens.

- The teacher educators should provide collaborative learning and application opportunities in science/math-specific groups for in-service teachers and pre-service teachers, as well as more diverse conglomerations of educators to promote co-planning and coteaching with English as a second language, special education, or STEM teachers.

Funding: No funding source is reported for this study. Declaration of interest: No conflict of interest is declared by the author.

\section{REFERENCES}

Acilis, S., Yalçı, S. A., \& Turgut, U: (2011). Effects of the $5 \mathrm{E}$ learning model on students' academic achievements in movement and force issues. Procedia-Social and Behavioral Sciences, 15, 2459-2462. https://doi.org/10.1016/j.sbspro.2011.04.128

Althauser, K. L. (2018). The emphasis of inquiry instructional strategies: Impact on preservice teachers' mathematics efficacy. Journal of Education and Learning, 7(1), 53-70. http://doi.org/ 10.5539/jel.v7n1p53

Ates, O., Unal Coban, G., \& Kaya Sengoren, S. (2018). Consistency between constructivist profiles and instructional practices of prospective physics teachers. European Journal of Educational Research, $7(2), \quad 359-372 . \quad$ https://doi.org/10.12973/eujer.7.2.359

Atkins, S., Lewin, S., Smith, H., Engel, M., Fretheim, A., \& Volmink, J. (2008). Conducting a metaethnography of qualitative literature: Lessons learnt. BMC Medical Research Methodology, 8(1), 21. https:// doi.org/10.1186/1471-2288-8-21

Bahng, E., \& Lee, M. (2017). Learning experiences and practices of elementary teacher candidates on the use of emerging technology: A grounded theory approach. International Electronic Journal of Elementary Education, 10(2), 225-241. https:/ / doi.org/10.26822/iejee.2017236118

Bang, E. (2013). Exploring impact of the EED 420 Science Methods Course on pre-service elementary teachers views regarding the nature of science. 
International Electronic Journal of Elementary Education, 5(3), 219-232.

Barnett-Page, E., \& Thomas, J. (2009). Methods for the synthesis of qualitative research: A critical review. BMC Medical Research Methodology, 9, Article 59. https:/ / doi.org/10.1186/1471-2288-9-59

Biber, A. C., Tuna, A., Gulsevincler, D., \& Karaosmanoglu, A. B. (2015). The view of mathematics teachers about the 5E instructional model. Erzincan Universitesi Egitim Fakultesi Dergisi, 17(1), 175-196. https:/ / doi.org/10.17556/jef.02989

Bozdogan, A. E., \& Altunçekic, A. (2007). Fen bilgisi ogretmen adaylarinin 5E ogretim modelinin kullanilabilirligi hakkındaki gorusleri [The opinions of science teacher candidates about the usability of the $5 \mathrm{E}$ teaching model]. Kastamonu Egìtim Dergisi, 15(2), 579-590.

Bybee, R. W. (2014). The BSCS 5E instructional model: Personal reflections and contemporary implications. Science and Children, 51(8), 10-13. https://doi.org/10.2505/4/sc14_051_08_10

Bybee, R. W., Taylor, A. J., Gardner, A., Van Scotteer, P., Powell, J. C., Westbrook, A., \& Landes, N. (2006). The BSCS 5E instructional model: Origins, effectiveness, and applications [Full report]. Colorado Springs, CO: Biological Science Curriculum Study.

Campbell, R., Pound, P., Pope, C., Britten, N., Pill, R., Morgan, J., \& Donovan, J. (2003). Evaluating metaethnography: A synthesis of qualitative research on lay experiences of diabetes and diabetes care. Social Science $\mathcal{E} \quad$ Medicine, 56(4), 671-684. https:/ / doi.org/10.1016/S0277-9536(02)00064-3

Celik, H., Pektaş, H. M., \& Karamustafaoğlu, O. (2018). Science teaching laboratory applications: Common knowledge construction, learning cycle models and stem approach. International Journal on New Trends in Education and Their Implications, 9(3), 11-29.

Demirbas, M., \& Pektas, H. M. (2015). Evaluation of experiments conducted about 5E learning cycle model and determination of the problems encountered. International Online Journal of Educational Sciences, 7(1), 51-64. https://doi.org/ 10.15345/iojes.2015.01.005

Duran, L. B., \& Duran, E, (2004). The 5E instructional model: A learning cycle approach for inquiry-based science teaching, The Science Education Review, 3(2), 49-58.

Duran, L. B., McArthur, J., \& Hook, S. V. (2004). Undergraduate students' perceptions of an inquiry-based physics course. Journal of Science Teacher Education, 15(2), 155-171. https:/ / doi.org/10.1023/ B:JSTE.000

Enugu, R., \& Hokayem, H. (2017). Challenges preservice teachers face when implementing a $5 \mathrm{E}$ inquiry model of instruction. European Journal of Science and Mathematics Education, 5(2), 178-209.

Fletcher, S. S., \& Luft, J. A. (2011). Early career secondary science teachers: A longitudinal study of beliefs in relation to field experiences. Science Education, 95(6), 1124-1146. https://doi.org/10.1002/ sce. 20450

Iscan, C. D., Bayraktar, A., \& Gokce, E. (2015). Preservice teachers' teaching applications based on $5 \mathrm{E}$ learning cycle. Anthropologist, 20(1, 2), 319-329. https://doi.org/10.1080/09720073.2015.11891730

Kirschner, P., \& Selinger, M. (2003). The state of affairs of teacher education with respect to ICT. Technology, Pedagogy and Education, 12(1), 5-18. https:/ / doi.org/10.1080/14759390300200143

Lewis, E., Dema, O., \& Harshbarger, D. (2014). Preparation for practice: Elementary preservice teachers learning and using scientific classroom discourse community instructional strategies. School Science and Mathematics, 114(4), 154-165. https: / / doi.org/10.1111/ssm.12067

Lincoln, Y. S., \& Guba, E. G. (1985). Naturalistic inquiry. Sage. https://doi.org/10.1016/0147-1767(85)90062 $-8$

Ludvigsen, M. S., Hall, E. O., Meyer, G., Fegran, L., Aagaard, H., \& Uhrenfeldt, L. (2016). Using Sandelowski and Barroso's meta-synthesis method in advancing qualitative evidence. Qualitative Health Research, 26(3), 320-329. https://doi.org/ $10.1177 / 1049732315576493$

Maier, S. J., \& Marek, E. A. (2006). The learning cycle: A reintroduction. The Physics Teacher, 44(2), 109-113. https:// doi.org/10.1119/1.2165443

Marshall, J. C., \& Smart, J. B. (2013). Teachers' transformation to inquiry-based instructional practice. Creative Education, 4(2), 132-142. https: / / doi.org/10.4236/ce.2013.42019

Merriam, S. B. (1998). Qualitative research and case study applications in education. Jossey-Bass.

Metin, M., \& Ozmen, H. (2009). Sinif ogretmeni adaylarinin yapilandirmaci kuramin 5E modeline uygun etkinlikler tasarlarken ve uygularken karsilastiklari sorunlar [Problems faced by prospective classroom teachers while designing and implementing activities in accordance with the 5E model of constructivist theory]. Necatibey Egitim Fakultesi Elektronik Fen ve Matematik Egitimi Dergisi, 3(2), 94-123.

Metin, M., Coskun, K., Birisci, S., \& Kaleli Yilmaz, G. (2011). Opinions of prospective teachers about utilizing the 5E instructional model. Energy Education Science and Technology Part B: Social and Educational Studies, 3(4), 411-422.

Namdar, B., \& Kucuk, M. (2018). Preservice science teachers' practices of critiquing and revising $5 \mathrm{E}$ 
lesson plans. Journal of Science Teacher Education, 29(6), 468-484. https://doi.org/10.1080/1046560X. 2018.1469188

Noblit, G., \& Hare, R. (1988). Meta-ethnography: Synthesizing qualitative studies. Sage. https:// doi.org/10.4135/9781412985000

Polgampala, A. S. V., Shen, H., \& Huang, F. (2016). The impact on teaching through 5E model: Perspectives of prospective teachers in teaching science in secondary in Gampaha District Sri Lanka. Educational Perspectives, 5(1), 33-47.

Qablan, A. M., \& DeBaz, T. (2015). Facilitating elementary science teachers' implementation of inquiry-based science teaching. Teacher Development, 19(1), 3-21. https://doi.org/10.1080/ 13664530.2014 .959552

Rehmat, A. P., \& Bailey, J. M. (2014). Technology integration in a science classroom: Preservice teachers' perceptions. Journal Science Education Technology, 23, 744-755. https://doi.org/10.1007/ s10956-014-9507-7

Ross, D. K., \& Cartier, J. L. (2015). Developing pre-service elementary teachers' pedagogical practices while planning using the learning cycle. Journal of Science Teacher Education, 26(6), 573-591. https:/ / doi.org/10.1007/s10972-015-9439-y

Sahin, C., Cavus, S., \& Gungoren S. (2013). Examining usage trends of computer support of the prospective primary school teachers in the science education based on the 5E model. Social and Behavioral Sciences, 116, 1913-1918. https:/ / doi.org/ 10.1016/j.sbspro.2014.01.494

Savenye, W. C., \& Robinson, R. S. (2005). Using qualitative research methods in higher education. Journal of Computer Higher Education,16(2), 65-95. https:/ / doi.org/10.1007/BF02961475

Shaw, R. L., Booth, A., Sutton, A. J., Miller, T., Smith, J. A., Young, B., Jones, D. R., \& Dixon-Woods, M. (2004). Finding qualitative research: An evaluation of search strategies. BMC Medical Research Methodology, 16, 4-5. https://doi.org/10.1186/ 1471-2288-4-5
Sickel, A. J., \& Friedrichsen, P. (2015). Belief, practice knowledge, and context: A longitudinal study of a begging biology teacher's 5E unit. School Science and Mathematics,115(2), 75-87. https:// doi.org/10.1111 /ssm.12102

Smolleck, L., \& Mongan, A. (2011). Changes in preservice teachers' self-efficacy: From science methods to student teaching. Journal of Educational and Development Psychology, 1(1), 133-145. https://doi.org/10.5539/jedp.v1n1p133

Spillane, J. P., \& Zeuli, J. S. (1999). Reform and teaching: Exploring patterns of practice in the context of national and state mathematics reforms. Educational Evaluation and Policy Analysis, 21(1), 1-27. https://doi.org/10.3102/01623737021001001

Toraman, C., \& Demir, E. (2016). The effect of constructivism on attitudes towards lessons: A meta-analysis study. Eurasian Journal of Educational Research, 16(62), 115-142. https:/ / doi.org/10.14689 / ejer.2016.62.8

Turan, S., \& Matteson, S. M. (2021). Middle school mathematics classrooms practice based on $5 \mathrm{E}$ instructional model. International Journal of Education in Mathematics, Science, and Technology (IJEMST), 9(1), 22-39. https://doi.org/10.46328/ ijemst.1041

Varma, T., Volkmann, M. J., \& Hanuscin, D. L. (2009). Preservice elementary teachers' perceptions of their understanding of inquiry and inquiry-based science pedagogy: Influence of an elementary science education methods course and a science field experience. Journal of Elementary Science Education, 21(4), 1-22. https://doi.org/10.1007/ BF03182354

Walia, P. (2012). Effect of 5E instructional model on mathematical creativity of students. Golden Research Thought, 1(10), 1-4.

Yildiz, B., \& Kocak Usluel, Y. (2016). A model proposal on ICT integration for effective mathematics instruction. Hacettepe University Journal of Education, 31(1), 14-33. https://doi.org/10.16986/HUJE. 2015013971 


\section{APPENDIX A}

\section{Study Selection}

\begin{tabular}{|c|c|c|c|c|c|}
\hline & Study & Method & Participant(s) & Context/Setting & Country \\
\hline 1 & Acilis, Yalcin, \& Turgut (2011) & Qual & Sci PST & UMC & Turkey \\
\hline 2 & Althauser (2018) & MMR & Math PST & UMC & USA \\
\hline 3 & Ates, Unal Coban, \& Kaya Sengoren (2018) & Qual & Physics PST & UMC & Turkey \\
\hline 4 & Bahng and Lee (2017) & Qual & Sci PST & UMC & USA \\
\hline 5 & Bang (2013) & Qual & Sci PST & UMC & USA \\
\hline 6 & Bozdogan \& Altuncekic (2007) & Qual & Sci PST & UMC & Turkey \\
\hline 7 & Celik, Pektas, \& Karamustafaoglu (2018) & Qual & Sci PST & UMC & Turkey \\
\hline 8 & Demirbas \& Pektas (2015) & Qual & Sci PST & UMC & Turkey \\
\hline 9 & Duran, McArthur, and Hook (2004) & Qual & Sci PST & UMC & USA \\
\hline 10 & Enugu \& Hokayem (2017) & Qual & Sci PST & UMC & USA \\
\hline 11 & Fletcher \& Luft (2011) & Qual & Sci PST & UMC & USA \\
\hline 12 & Goldston et al. (2013) & Quan & Sci PST & UMC & USA \\
\hline 13 & Iscan, Bayraktar, \& Gokce (2015) & Qual & Math \& Sci PST & UMC & Turkey \\
\hline 14 & Lewis, Dema, \& Harsbarger (2014) & MMR & Sci PST & UMC & USA \\
\hline 15 & Luera, Moyer, and Everett (2005) & Quan & Sci PST & UMC & USA \\
\hline 16 & Metin et. al (2011) & Qual & Sci PST & UMC & Turkey \\
\hline 17 & Metin \& Ozmen (2009) & Qual & Sci PST & UMC & Turkey \\
\hline 18 & Namdar \& Kucuk (2018) & Qual & Sci PST & UMC & Turkey \\
\hline 19 & Polgampala, Shen, \& Huang (2016) & Qual & Math \& Sci PST & UMC & Sri Lanka \\
\hline 20 & Qablan \& DeBaz (2015) & Qual & Sci PST & UMC & Jordan \\
\hline 21 & Rehmat \& Bailey (2014) & Qual & Sci PST & UMC & USA \\
\hline 22 & Ross \& Cartier (2015) & MMR & Sci PST & UMC & USA \\
\hline 23 & Sahin, Cavus, \& Gungore (2014) & Qual & Sci PST & UMC & Turkey \\
\hline 24 & Smolleck \& Mongan (2011) & MMR & Sci PST & UMC & USA \\
\hline 25 & Varma, Volkmann, \& Hanuscin (2009) & Qual & Sci PST & UMC & USA \\
\hline 26 & Yildiz \& Kocak Usluel (2016) & Qual & Math PST & UMC & Turkey \\
\hline
\end{tabular}

Note. Pre-Service Teacher (PST), In-Service Teacher (IST), Science (Sci), Mathematics (Math), Qualitative (Qual), Quantitative (Quan), Mixed Methods Research (MMR), Observation (Obs), Interview (Int), Document (Doc), Professional Development (PD), University Method Course (UMC). 


\section{APPENDIX B}

\section{Selecting Studies}

\begin{tabular}{|c|c|c|c|c|c|}
\hline Study & Participant & Design & Procedures & Data Analyse & Findings \\
\hline Althauser (2018) & $\begin{array}{l}347 \text { Math PST } \\
12 \text { Math PST }\end{array}$ & $\begin{array}{l}\text { MMR, Qual Not } \\
\text { specify (Int, Obs) }\end{array}$ & $\begin{array}{l}3 \text { steps: Teach, } \\
\text { Apply, and Reflect }\end{array}$ & \multicolumn{2}{|c|}{ Analytical Coding Organized themes } \\
\hline $\begin{array}{l}\text { Bozdogan and Altuncekic } \\
(2007)\end{array}$ & 30 Science PST & $\begin{array}{l}\text { Descriptive Qual } \\
\text { Study (Int, Doc) }\end{array}$ & $\begin{array}{l}3 \text { steps: Teach, } \\
\text { Apply, and Reflect }\end{array}$ & Content analysis & $\begin{array}{l}\text { Calculated frequency } \\
\text { Organized themes }\end{array}$ \\
\hline $\begin{array}{l}\text { Celik, Pektas, and } \\
\text { Karamustafaoglu (2018) }\end{array}$ & 40 Science PST & Qual Research (Int) & $\begin{array}{l}3 \text { steps: Teach, } \\
\text { Apply, and Reflect }\end{array}$ & Content analysis & Organized themes \\
\hline $\begin{array}{l}\text { Demirbas and Pektas } \\
\text { (2015) }\end{array}$ & 40 Science PST & $\begin{array}{l}\text { Case Study (Int, } \\
\text { Obs, Doc) }\end{array}$ & $\begin{array}{l}3 \text { steps: Teach, } \\
\text { Apply, and Reflect }\end{array}$ & Content analysis & $\begin{array}{l}\text { Calculated frequency } \\
\text { Organized themes }\end{array}$ \\
\hline $\begin{array}{l}\text { Duran, McArthur, and } \\
\text { Hook (2004) }\end{array}$ & 25 Science PST & Not specify (Int) & $\begin{array}{l}2 \text { steps: Teach, } \\
\text { Reflect }\end{array}$ & Content analysis & Organized themes \\
\hline $\begin{array}{l}\text { Enugu and Hokayem } \\
\text { (2017) }\end{array}$ & 55 Science PST & $\begin{array}{l}\text { Case Study (Int, } \\
\text { Obs, Doc) }\end{array}$ & $\begin{array}{l}3 \text { steps: Teach, } \\
\text { Apply, and Reflect }\end{array}$ & Content analysis & $\begin{array}{l}\text { Calculated frequency } \\
\text { Organized themes }\end{array}$ \\
\hline Fletcher and Luft (2011) & 17 Science PST & $\begin{array}{l}\text { Case Study (Int, } \\
\text { Doc) }\end{array}$ & $\begin{array}{l}2 \text { steps: Teach, } \\
\text { Reflect }\end{array}$ & Content analysis & Organized themes \\
\hline $\begin{array}{l}\text { Iscan, Bayraktar, and } \\
\text { Gokce (2015) }\end{array}$ & $\begin{array}{l}15 \text { Math \& } \\
\text { Science PST }\end{array}$ & $\begin{array}{l}\text { Descriptive Qual } \\
\text { Study (Obs, Doc) }\end{array}$ & $\begin{array}{l}3 \text { steps: Teach, } \\
\text { Apply, and Reflect }\end{array}$ & Content analysis & $\begin{array}{l}\text { Calculated frequency } \\
\text { Organized themes }\end{array}$ \\
\hline Metin et al. (2011) & 60 Science PST & Qual study (Int) & $\begin{array}{l}3 \text { steps: Teach, } \\
\text { Apply, Reflect }\end{array}$ & Content analysis & $\begin{array}{l}\text { Calculated frequency } \\
\text { Organized themes }\end{array}$ \\
\hline Metin and Ozmen (2009) & 25 Science PST & $\begin{array}{l}\text { Qualitative study } \\
\text { (Int, Obs) }\end{array}$ & $\begin{array}{l}3 \text { steps: Teach, } \\
\text { Apply, Reflect }\end{array}$ & Content analysis & $\begin{array}{l}\text { Calculated frequency } \\
\text { Organized themes }\end{array}$ \\
\hline $\begin{array}{l}\text { Smolleck and Mongan } \\
\text { (2011) }\end{array}$ & 38 Science PST & $\begin{array}{l}\text { MMR Qual Not } \\
\text { specify (Int) }\end{array}$ & $\begin{array}{l}3 \text { steps: Teach, } \\
\text { Apply, Reflect }\end{array}$ & Content analysis & $\begin{array}{l}\text { Calculated frequency } \\
\text { Organized themes }\end{array}$ \\
\hline $\begin{array}{l}\text { Namdar and Kucuk } \\
\text { (2018) }\end{array}$ & 51 Science PST & Case Study (Doc) & $\begin{array}{l}3 \text { steps: Teach, } \\
\text { Apply, Reflect }\end{array}$ & Content analysis & Organized themes \\
\hline $\begin{array}{l}\text { Polgampala, Shen, and } \\
\text { Huang (2016) }\end{array}$ & $\begin{array}{l}60 \text { Math \& } \\
\text { Science PST }\end{array}$ & $\begin{array}{l}\text { MMR, Qual Not } \\
\text { Specify (Int, Obs) }\end{array}$ & $\begin{array}{l}3 \text { steps: Teach, } \\
\text { Apply, and Reflect }\end{array}$ & Content analysis & nized themes \\
\hline Qablan and DeBaz (2015) & 80 Science PST & $\begin{array}{l}\text { Qual Study (Int, } \\
\text { Doc) }\end{array}$ & $\begin{array}{l}3 \text { steps: Teach, } \\
\text { Apply, and Reflect }\end{array}$ & Content analysis & Organized themes \\
\hline $\begin{array}{l}\text { Varma, Wolkmann, and } \\
\text { Hanuscin (2009) }\end{array}$ & 40 Science PST & $\begin{array}{l}\text { Qual study (Int, } \\
\text { Doc) }\end{array}$ & $\begin{array}{l}2 \text { steps: Teach, } \\
\text { Reflect }\end{array}$ & Content analysis & $\begin{array}{l}\text { Calculated frequency } \\
\text { Organized themes }\end{array}$ \\
\hline $\begin{array}{l}\text { Yildiz, Kocak Usluel } \\
\text { (2016) }\end{array}$ & 47 Math PST & $\begin{array}{l}\text { Design-Based } \\
\text { Research (Int, Obs, } \\
\text { Doc) }\end{array}$ & $\begin{array}{l}3 \text { steps: Teach, } \\
\text { Apply, and Reflect }\end{array}$ & $\begin{array}{l}\text { Frequency and } \\
\text { content analysis }\end{array}$ & Organized themes \\
\hline $\begin{array}{l}\text { Acilis, Yalcin, and Turgu } \\
\text { (2011) }\end{array}$ & nce PST & Case study (Doc) & $\begin{array}{l}2 \text { steps: Teach, } \\
\text { Apply }\end{array}$ & $\begin{array}{l}\text { Doc } \\
\text { Ana }\end{array}$ & Calculated frequency \\
\hline $\begin{array}{l}\text { Ates, Unal Coban, and } \\
\text { Kaya Sengoren (2018) }\end{array}$ & 11 Physics PST & $\begin{array}{l}\text { Case Study (Int, } \\
\text { Obs, Doc) }\end{array}$ & $\begin{array}{l}3 \text { steps: Teach, } \\
\text { Apply, and Reflect }\end{array}$ & Content analysis & Calculated frequency \\
\hline Bahng and Lee (2017) & 229 Sci PST & $\begin{array}{l}\text { Grounded Theory } \\
\text { (Int, Obs, Doc) }\end{array}$ & $\begin{array}{l}3 \text { steps: Teach, } \\
\text { Apply, and Reflect }\end{array}$ & $\begin{array}{l}\text { Constant } \\
\text { Comparative }\end{array}$ & $\begin{array}{l}\text { Organized themes } \\
\text { (not related to teacher } \\
\text { experiences) }\end{array}$ \\
\hline Bang (2013) & 21 Sci PST & Qual (Int, Obs, Doc) & $\begin{array}{l}3 \text { steps: Teach, } \\
\text { Apply, and Reflect }\end{array}$ & Content analysis & $\begin{array}{l}\text { Calculated frequency } \\
\text { Organize themes (not related to } \\
\text { teacher experiences) }\end{array}$ \\
\hline $\begin{array}{l}\text { Lewis, Dema, and } \\
\text { Harsbarger (2014) }\end{array}$ & 16 Science PST & $\begin{array}{l}\text { MMR, Qual Not } \\
\text { Specify (Int, Doc) }\end{array}$ & $\begin{array}{l}3 \text { steps: Teach, } \\
\text { Apply, and Reflect }\end{array}$ & Content analysis & $\begin{array}{l}\text { Calculated frequency } \\
\text { Organized themes (not related } \\
\text { to teacher experiences) }\end{array}$ \\
\hline Rehmat and Bailey (2014) & 15 Sci PST & Qual (Int, Doc) & $\begin{array}{l}3 \text { steps: Teach, } \\
\text { Apply, and Reflect }\end{array}$ & Content analysis & $\begin{array}{l}\text { Calculated frequency } \\
\text { Organized themes (not related } \\
\text { to teacher experiences) }\end{array}$ \\
\hline Ross and Cartier (2015) & 51 Science PST & $\begin{array}{l}\text { MMR, Qual Not } \\
\text { Specify (Int, Doc) }\end{array}$ & $\begin{array}{l}3 \text { steps: Teach, } \\
\text { Apply, and Reflect }\end{array}$ & Content analysis & Calculated frequency \\
\hline $\begin{array}{l}\text { Sahin, Cavus, and } \\
\text { Gungoren (2014) }\end{array}$ & 154 Science PST & Case study (Int) & $\begin{array}{l}3 \text { steps: Teach, } \\
\text { Apply, and Reflect }\end{array}$ & Content analysis & Calculated frequency \\
\hline $\begin{array}{l}\text { Turan and Matteson } \\
(2020)\end{array}$ & 7 Math Teacher & $\begin{array}{l}\text { Case study (Obs, } \\
\text { Doc) }\end{array}$ & & sis & \\
\hline
\end{tabular}

Note. Pre-Service Teacher (PST), In-Service Teacher (IST), Science (Sci), Mathematics (Math), Qualitative (Qual), Quantitative (Quan), Mixed Methods Research (MMR), Observation (Obs), Interview (Int), Document (Doc), Professional Development (PD), University Method Course (UMC).

\section{http://www.ejmste.com}

